Dialectologia. Special issue, $\boldsymbol{V}$ (2015), 167-190.

ISSN: 2013-2247

Received 18 March 2015.

Accepted 15 June 2015.

\title{
ON THE USE OF THE ARTICLE WITH PEOPLE'S PROPER NAMES IN GALICIAN ${ }^{1}$
}

\author{
Eduardo LOUREDO RODRÍGUEZ \\ Instituto da Lingua Galega - Universidade de Santiago de Compostela \\ eduardo.louredo@usc.es
}

Abstract

This paper examines the use of the definite article with proper names designating people in Galician. In Galician there is an area where the definite article can be used with proper names and another where this does not occur (Álvarez \& Xove 2002: 380; Sousa 1994). Thus some speakers produce utterances such as A Luísa veu onte (DEF.ART- Luísa came yesterday) whereas other people say Luísa veu onte (Luísa came yesterday).

The paper looks at this question while seeking to contribute to the study of Galician dialect variation, still inadequately described, through comparison with what occurs in other (particularly Romance) languages. It commences with a review of the functions of the definite article and the semantic characteristics of personal names (Gary-Prieur 1994; Van Langendonck 2007), and looks at the extent of the phenomenon and its social status in other languages, especially in Romance. The next section describes the dialectal distribution of the use of the article with proper names in Galician based on two twentieth-century geolinguistic studies, Atlas Lingüístico de la Península lbérica (ALPI) and Atlas Lingüístico Galego (ALGa), in order to establish where the phenomenon occurs.

In this connection, following an assessment of the usefulness of studies in linguistic geography for studying syntactic variation, it will be concluded that one must be very cautious about using the ALPI

\footnotetext{
${ }^{1}$ This study was undertaken as part of the framework of the "Linguistic Change in Current Galician" project (Ref. FFI2012-33845), financed by the Spanish Ministry of Economics and Competitivity, and my doctoral thesis, "Linguistic Variation and Change in Apparent Time: Ribeiro Galician". This work has been supported in part by the Xunta de Galicia (Consellería de Cultura, Educación e Ordenación Universitaria) and the European Union (under grant code GRC2013/40). I would like to thank Xulio Sousa for his observations on previous versions of this article. I would also like to express my gratitude to Raquel Vila Amado, Marta Negro and César Osorio for their help in processing data. Any errors are entirely my own.
} 
data, on account of certain methodological problems that we perceive in this atlas. As our main conclusion, we will argue that the motivation for the use of the article with proper names in Galician is a process of the article's functional expansion, also observed in other languages (Lyons 1999). In an attempt to demonstrate this hypothesis, the phenomenon is compared to the use of the article with another set of nouns, kinship terms, which share some semantic features with proper names.

\section{Keywords}

Galician, syntax, linguistic geography, definite article, proper names

\section{O USO DO ARTIGO CON NOME DE PERSOA EN GALEGO}

\section{Resumo}

Este traballo aborda o estudo do emprego de artigo definido con nome de propio de persoa en galego. Na lingua galega existe unha zona na que o artigo definido pode acompañar o nome propio e outra na que non se dá este fenómeno (Álvarez \& Xove 2002: 380; Sousa 1994). Deste xeito, hai falantes que producen enunciados coma $A$ Luísa veu onte (ART. DET.- Luísa came yesterday) mentres que outros din Luísa veu onte (Luísa came yesterday).

No artigo estúdase este fenómeno e contribúese á análise da variación dialectal en galego, aínda pouco estudada e faino tratando de poñelo en relación co que sucede noutras linguas, sobre todo románicas. En primeiro lugar, faise un repaso das funcións do artigo determinado e as características semánticas dos nomes propios de persoa (Gary-Prieur 1994; Van Langendonck 2007). Estúdase tamén a extensión e valoración social do fenómeno noutras linguas, sobre todo románicas. Na seguinte sección, analízase a distribución dialectal do uso do artigo con nome propio en galego a partir dos dous traballos de xeolingüística realizados no século pasado, o Atlas Lingüístico de la Península Ibérica (ALPI) e o Atlas Lingüístico Galego ( $\mathrm{LLGa}$ ), co fin de determinar a extensión territorial do fenómeno. Relacionado con isto, faise unha valoración da utilidade dos estudos de xeografía lingüística para o estudo da variación sintáctica e determínase que cómpre ser moi coidadoso co emprego dos datos do ALPI. Isto débese, na nosa opinión, a problemas metodolóxicos deste atlas. Finalmente, como conclusión principal, arguméntase que o uso de artigo con nome propio en galego está motivado por un proceso de expansión funcional do artigo, rexistrado noutras linguas (Lyons 1999). Tratamos de demostrar esta hipótese relacionando o fenómeno estudado co emprego do artigo con outros nomes (os nomes de parentesco) que comparten algunhas características semánticas cos nomes propios.

\section{Palabras clave}

galego, sintaxe, xeografía lingüística, artigo definido, nome propio

\section{Introduction}

In Galician, as in other Romance languages, a person's proper name (forthwith, PN) can be accompanied by a definite article. This fact, which has not been researched 
in depth, represents an interesting problem in grammatical terms. This study will attempt to provide greater analysis of this matter. It will take into account previous works and seek explanatory procedures based on the linguistic characteristics of articles and proper names, and the data made available to us through oral language.

Firstly, I wish to point out that the object of study in this work are people's proper names, excluding toponyms and anthroponyms such as nicknames and surnames. The PNs of historical figures (for example, Napoleon or Dante) are not taken into account either, since they display behaviour which does not always coincide with the PNs of ordinary people. In general, this type of PN does not tend to be accompanied by the article (Álvarez \& Xove 2002: 380; Raposo 2013: 1025). The use of the article with the PN of a historical figure may be on account of an attempt to underestimate the importance of the figure or rather a wish to demonstrate a knowledge of their historical, literary or cultural importance, etc. (Vázquez \& Mendes da Luz $1971^{3}$ : 129).

\section{The definite article and the PN: semantic characteristics and syntantical functions}

The Galician definite article, equivalent to the English the, is formed by a paradigm of four elements which possess different values of gender (masculine and feminine) and number (singular and plural): $o, a, o s, a s$. The two principle functions which the article performs are that of actualization and identification (Álvarez \& Xove 2002: 440; Escandell 1997: 10-11). Actualization allows a virtual concept, which exists in the speaker's mind; for example, libro ('book') can be employed in utterances such as $O$ libro que lin gustoume moito ('I really liked the book that I read') or Pon os libros na mesa ('Put the books on the table'). Naturally, this operation can also be carried out by other units such as gender and number morphemes, or by other elements regarded customarily as articles: the indefinite artcle (Comprei un libro, 'I bought a book'), demonstratives (Comprei este libro hoxe, 'I bought this book today'), etc.

Identification operations allow that to which the transmitter refers, from amongst all the potential references, to be selected. In spite of demonstratives, 
possessives, etc. realizing identification operations, "the basic identification, that is, the presentation of what we refer to as known for the hearer" is accomplished fundamentally by the article" (Álvarez \& Xove 2002: 440). ${ }^{2}$ That is, whilst other determiners such as demonstratives or possessives add other values to the Noun Phrase (NP), "the sole and essential function of the article is to present the nominal entity which follows as determined (...). The article acts as a presenter and actualizer of a noun, which is accessible to the listener" ${ }^{3}$ (Company 2009: 791; cf. also Ortiz Ciscomani 2009: 354; Miguel \& Raposo 2013: 823; Raposo 2013: 1029).

Unlike the article, the majority of studies on the PN focussed more on the analysis of its values than of its combinatorial qualities. There are few works published on specific languages and scarce group studies which examine the PN from different perspectives. ${ }^{4}$ The central theme of the debate is whether the PN possess meaning and if so whether it is a referential or lexical meaning. But this debate only affects the objectives of this present study tangentially.

Amongst the semantic characteristics which the PN possess, the following stand out (Fernández Leboráns 1999: 80):

a) Referential uniqueness (monoreferentiality), i.e. each PN has a unique reference.

b) A lack of lexical meaning.

c) The absence of a determiner in the prototypical referential function.

The last of these interests us most, given that it enters into apparent contradiction with the fact that on many occasions the article appears with the PN. Before this matter is addressed further, some concepts must be clarified. The first of these is the different between the prototypical (or primary) and non-prototypical (or secondary) referential function employed amongst others by Fernández Leboráns (1999). For Raposo (2013) and other authors the PN has three functions: the

\footnotetext{
2 "A identification básica, é dicir, a presentación daquilo ó que nos referimos como coñecido para o alocutario é realizada fundamentalmente polo artigo."

3 "La función esencial y única del artículo es presentar la entidad nominal que sigue como determinada (...). El artículo opera como un presentador y actualizador de un sustantivo, que es accesible al oyente." ${ }^{4}$ The matter in question can be approached through two complete monographs on the subject, which are the studies of Van Langendonck (2007: 22-84) and Gary-Prieur (1994: 9-62).
} 
Dialectologia. Special issue, $\mathbf{V}$ (2015), 167-190.

ISSN: 2013-2247

referential, the denominative and the vocative. The referential function is what is regarded as prototypical or primary in the PN.

Nesta função, os nomes próprios no singular referem uma entidade particular num determinado contexto situacional ou discursivo, entidade essa identificada pelo falante através do seu nome (Raposo, 2013: 1013). ${ }^{5}$

In this case, the denominative and vocative functions are considered secondary. In the vocative function, the PN is used "by the speaker in order to address the listener" ${ }^{6}$ (Raposo 2013: 1016), as in (1).

(1) Antonio, cando chegas a Santiago? ('Antonio, when do you arrive in Santiago?').

In the denominative function, however, the PN is employed just as a "label' and does not have any referential function"7 (Raposo 1013: 105). It is the use reflected in the examples (2) and (3).

(2) A miña muller chámase Sara. ('My wife's name is Sara').

(3) Nesa aldea hai moitas Marías ('In that village there are many Marías').

That is, the PN ends up being a common noun which has the meaning of 'a person who has that name'. This use is what is denominated modified ("modificado") by different authors (cfr. Fernández Leboráns 1999) and in the case of this use the PN takes the definite article as much as other restrictive modifiers, as can be seen in examples (4) and (5).

(4) A María que eu coñecín non era tan xenerosa. ('The María that I knew was not as generous').

\footnotetext{
${ }^{5}$ In this function, the singular proper nouns refer to a particular entity or determined situational or discursive context, the entity being identified by the speaker through their name.

6 "Pelo falante para se dirigir ao ouvinte." (Raposo 2013: 1013).

7 "«Etiqueta» e não têm qualquer função referencial."
} 
(5) Na miña clase hai dúas Saras e un David ('In my class there are two Saras and one David').

The fact that in the modified uses the PN can take an article leads many authors to conclude that, when this occurs, the PN stops being such and becomes a common noun, since "the PN is a syntactically self-determined and self-complementary category" (Fernández Leboráns 1999: 103; cf. also Brucart 2008: 1475). ${ }^{8}$ This opinion is also shared by Van Lagendonck (2007: 154) (“in the irreferential use, proper names are definite") and Gary-Prieur (1994: 69):

La détermination inhérente au nom propre va donc encore plus loin qu'on ne le di généralement dans les grammaires: non seulement le nom propre «n'a pas besoind'article», mais encore il ne tolére aucune forme de détermination, c'est-adire aucune présentation restrictive du référent initial. ${ }^{9}$

Therefore, an eventual use of the article with the PN, of the self-determined category, should respond to another type of cause for these authors. For Van Lagendonck (2007: 221), "personal names normally have no article. If they do display one (for example, marginally in Dutch dialects), it is mainly for emotive (augmentative) reasons". For his part, Gary-Prieur (1994: 65-66) states that:

Il est raisonnable de penser qu'étant données les propriétés spécifiques du nom propre, sa combinaison dans un SN avec un déterminant et une éventuelle expansion ne s'effectue pas de la même façon que pour un nom commun. Avec un nom commun, le déterminant et l'expansion ont une double fonction: contribuer à sélectioner la signification du nom parmi les différents sens lexicaux possibles, et délimiter l'entendue de cette signification, autrement dit permettre le repérage du référent. ${ }^{10}$

\footnotetext{
8 "El PN es una categoría sintácticamente autodeterminada y autocomplementada."

${ }^{9}$ The inherent determination of the proper noun therefore goes further than is generally the case in grammars: not only does the proper noun "have no need of the article" but it even tolerates no form of determination; that is, no restrictive presentation of the initial reference.

${ }^{10}$ It is reasonable to think that with being given the specific properties of the proper noun, their combination within a nominal syntagm with a determiner and an eventual expansion does not take
} 
The use of the article with the PN is restricted for these authors to uses characterised by familiarity and emotional values. When this occurs, according to Kleiber (1981 apud Fernández Leboráns 1999: 103, notes), the article is expletive. In this point, the obvious question is if the value of the emotionality explains all the occurrences of the article $+\mathrm{PN}$ in so many and so different languages or if other, more complex causes can be sought.

\section{Use and extension of the article $+P N$ in languages}

As has been stated, the use of the article with PN is not an exclusive phenomenon of Galician since it is also observed in other languages, both Romance and non-Romance. In the Germanic linguistic family there are languages in which the PN can appear with an article and others in which this is not possible. For example, in English the PN is never accompanied by an article. However, in some southern and northern varieties of German the PN can go with the article (Coromina 2001: 52-53). Also in Dutch it is possible for the PN to be accompanied by the article in order to express "emotional" values (Van Langendonck 2007: 158).

In the Balkan languages studied by Souza (1994 apud Amaral 2003: 134-138) the opposite case obtains: languages from different families share this phenomenon. According to this author, in Greek ${ }^{11}$ and Albanian the PN always appears with the article, in Bulgarian it is never employed whilst in Hungary this characteristic is found in informal styles. Finally, in Romanian, and now entering the Romance family group, the article accompanies feminine names and also masculine names when the latter are in the genitive and dative cases.

In the remaining Romance languages, this phenomenon is normally restricted in its extension by factors of a diatopic and diaphasic kind. In French and Italian, the use

place in the same way as with a common noun. With a common noun, the determiner and the expansion have a double function: to contribute to the selection of the meaning of the noun amongst the different possible lexical senses, and to delimit what is understood by this meaning. In other words, it allows the identification of the referent.

${ }^{11}$ In classic as well as modern Greek, the article is obligatory with the PN (Lyons 1999: 22). 
of the article with the PN is described as a characteristic of some regional varieties and of colloquial styles (Goosse 1993: 884; Dardano \& Trifone 1995: 157). According to these authors, in the case of Italian we find the structure studied in northern varieties (Venice, Lombardy, etc.), more frequently with feminine names (la Anna è stata qui) than with masculine names (Pietro è stato qui) (Lyons 1999: 122). In France, it is registered more notably in rural varieties ("campagnards").

In Castilian, the phenomenon is considered familiar and colloquial (Fernández Leboráns 1999: 113; Reynoso 2006) and exists in all geographical varieties of this language (Reynoso 2008). In Asturian and Aragonese, the article + PN is not registered. In the work by Andrés (2013: 329-330) on Peninsular languages, it is shown that this structure does not appear even in despective or appreciate contexts which, according to this author, are the only ones in which Galician as well as Castilian permit the use of the article with the PN.

In Catalan, the article appears frequently with the PN (el Pere, la Marta), although there are diaphasic differences, since it is more frequent in colloquial language than formal, and diatopic, as it does not have the same impact throughout the territory (Brucart 2008). In the Valencian Community and the Ebro districts the phenomenon is rare. In Catalonia it is very frequent and in the Balearics practically obligatory. In the latter language there also exists the determiner en ( $n a$ in the feminine), which is used exclusively with the PN (Coromina 2001). ${ }^{12}$

Finally, Galician and Portuguese behave in a similar way to Catalan (Coromina 2001: 18). Given that Galician will be studied in detail in the following section, I shall focus here on the Portuguese language. In spoken language, ${ }^{13}$ the use of the article with the PN is almost the total norm in Portugal and frequently in Brazil (Cintra \& Cunha 2000: 227; Vázquez \& Mendes da Luz 1971: 129-130). Therefore, the utterances (6) and (7) occur in Brazil, whilst in Portugal only utterance (6) is found:

\footnotetext{
${ }^{12}$ The existence of a determiner which is used in an exclusive manner with the PN also occurs in other languages that are more separated in typological and geographical terms, such as Tagalog and Maori (Lyons 1999: 123).

${ }^{13}$ In written language, the article is not accompanied by the PN; this occurs with more frequency than in spoken language.
} 
(6) O João veio ontem ('John came yesterday').

(7) João veio ontem ('John came yesterday').

The studies carried out on Brazilian Portuguese (cf. Amaral 2003 and Braga $2012)^{14}$ transmit the idea that the construction studied has less frequency in Brazil than in Portugal. It must be taken into account that in Brazil there are areas where the 'article $+\mathrm{PN}^{\prime}$ construction is more frequently used than in others and that semantic and syntactical contexts exist which favour more than others the use of the article with the PN (Amaral 2003; Braga 2012).

To conclude this section, it can be affirmed that many languages exist in which the use of the article with the PN is possible, in all or some of their varieties. In spite of its frequency, which is very important in some languages, this structure is denoted in the majority of studies as familiar, emotional, colloquial, etc. In the following section we shall see in greater detail the extension of this structure in Galician by examining the explanations that have been provided by different scholars.

\section{The use of the article with proper noun in Galician}

In spite of being a frequent phenomenon in Galician territory, the grammarians of Galician have not analyzed this matter to any great extent (Sousa 1994). The most attention that has been paid to it has been that by Álvarez \& Xove (2002: 380) who, like all modern grammarians, describe the phenomenon as colloquial and familiar. They therefore follow the interpretation, always without justification and rarely using comparison that has been made for other languages. These authors also underline that it is a matter of a phenomenon with diatopic distribution (it is not used in all areas) and diastratic (the youngest speakers would use it less than older people).

The mention of the diatopic distribution of the phenomenon is very relevant since it suggests that the construction 'article $+\mathrm{PN}^{\prime}$ ' does not occur, or does not occur with the same vitality, throughout Galicia. Given that for Galician we still do not

\footnotetext{
${ }^{14} \mathrm{Cf}$. In addition, the bibliography compiled by these authors.
} 
possess an oral corpus with texts from different locations in the territory, we will consult linguistic atlases in order to observe in what areas of Galicia the construction exists and in which it does not.

It should be taken into account, however, and above all for the study of syntax, that the linguistic atlases cannot substitute, only complement, oral corpora. Principally, because the questionnaires of the atlases were mostly centred upon the obtaining of phonetic and lexical information, with questions regarding syntax remaining scarce. For example, the Atlas Lingüístico de la Península Ibérica (ALPI) questionnaire comprises 828 questions regarding lexicon, 275 phonetics and 136 morphsyntax (Carrilho \& Sousa, 2012).

\subsection{Linguistic Geography data}

In spite of their limitations, linguistic atlases are extremely valuable sources for the study of languages. The first work of these characteristics which included the Galician linguistic domain was the ALPI, promoted by Menéndez Pidal and coordinated by Navarro Tomás. This atlas gathered information from the rural Romance varieties spoken in the first half of the 20th century. Even though gathered long beforehand, the data of this atlas only came partially to light in 1962 when the phonetics volume was published. Fortunately, the notebooks in which the responses were transcribed were not lost, and at present are being systematicized in a database in order to proceed at a later stage to their online publication (García Mouton 2010). The source of documentation for the ALPI data employed in this article is fundamentally the database for this present project.

Until the 1990s, Galician did not have its own linguistic atlas. The studies for the development of the Atlas Lingüístico Galego (ALGa) began in the 1970s and it was not until 1990 that the first volume was published. The ALGa is the best tool for studying the diatopical varieties of Galicia and the data from this atlas will also be used in this article. 


\subsubsection{ALPI}

The ALPI surveys in Galicia were carried out by Aníbal Otero between 1934 and 1935, with the help of Aurelio Espinosa (Jr.) in some locations in Ourense (Sousa, 2008). In order to consign the information from each one of the locations, two notebooks were employed. Notebook I was assigned to the gathering of phonetic and morphosyntactic information, whilst Notebook II focussed on lexicon. In Galicia, 53 places were researched. These were "towns and villages of medium size, in the majority of cases the principal location in the counties" (Sousa 2008: 304). ${ }^{15}$ The informants conformed to the NORM model (Non-mobile, Older, Rural, Male), which was employed in the Atlas Linguistique de la France by J. Guillièron and which was used in many later geographical linguistics projects (Chambers \& Trudgill 1994: 56-57).

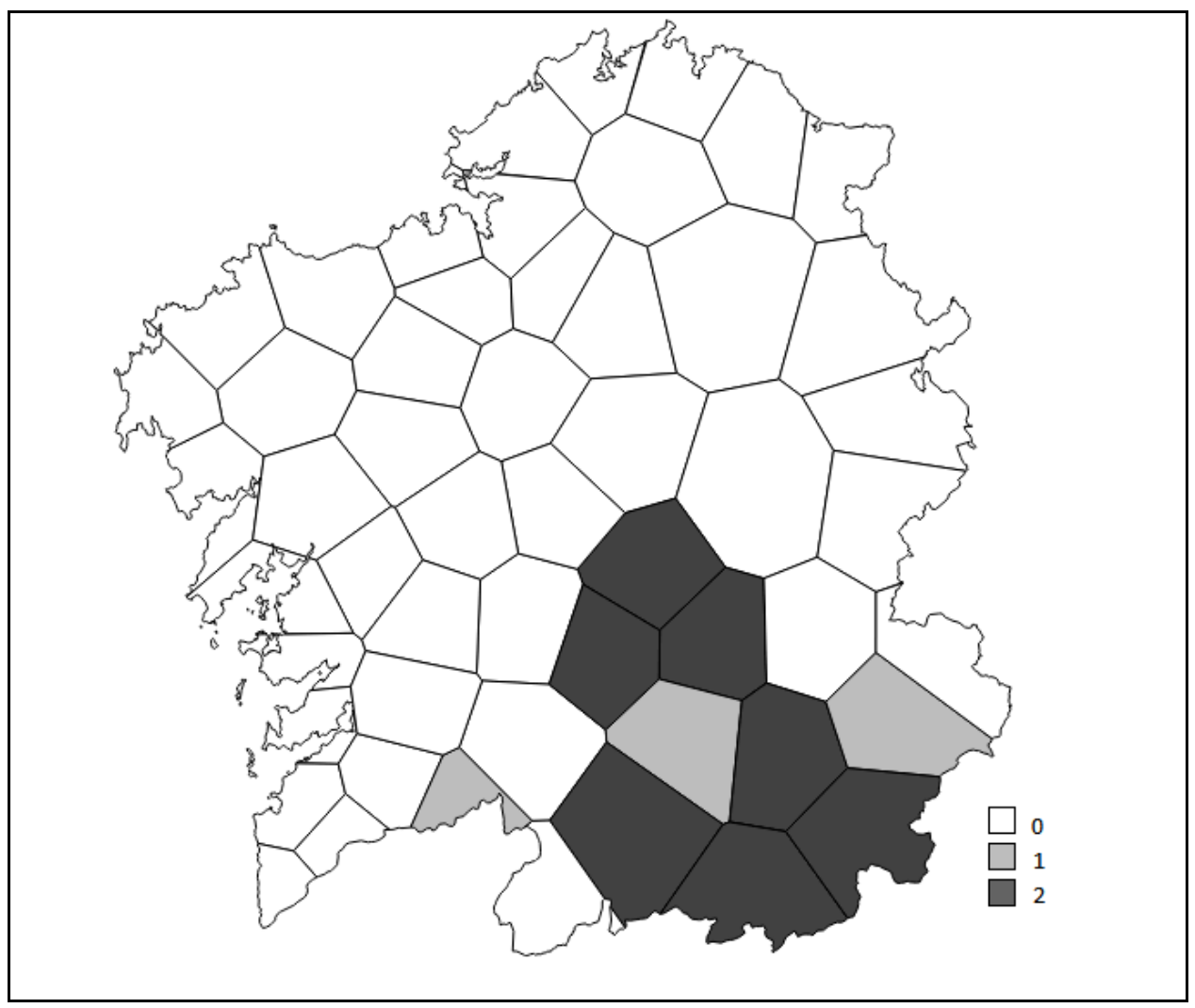

Map 1. Use of the article + PN according to the ALPI (Data from ALPI, questions 350, 376)

\footnotetext{
15 "Vilas e aldeas de tamaño mediano, na maioría dos casos cabeceiras de concellos."
} 
In Notebook I, two questions were included from which I will extract information for this work. These are question no. 350, A Miguel le cogieron preso ('Miguel was imprisoned') and no. 376, Anoche llegó Felipe ('Felipe arrived last night'). ${ }^{16}$ For the matter in question, we classified the responses into two groups according to whether the article was present (O Felipe/O Miguel) or not (Felipe/Miguel). With responses obtained for these questions Map 1 was developed, and on it is marked in dark grey the area where the article appears in the responses to the two questions, in light grey the places where the article only appears in one of the responses but not in the other, and in white those locations where the use of the article with the PN is not registered.

It can be observed how a continuous area exists on the map where the article appears with the PN. This concerns the greater part of Ourense province and various locations in those of Lugo and Pontevedra. ${ }^{17}$ The area, moreover, is almost continuous as only the location of Arbo (the most westerly) is located outside this area although it is very close to it.

\subsubsection{ALGa}

Before the Civil War there were few scientific descriptions of Galician produced within Galicia. This situation continued until almost the end of the Francoist dictatorship because of the regime's anti-Galician policy. The great impulse for studies on Galician came from the Instituto da Lingua Galega (Galician Language Institute) which, in the mid-1970s, undertook the ALGa fieldwork. From 1974 and 1976, a total of 167 locations were surveyed in Galicia and in the Galician-speaking areas of Asturias, León and Zamora. In the same way as in the case of the ALPI, informants replied to the NORM model: the majority of them were older, employed in the agricultural sector and had practically never left their villages.

\footnotetext{
${ }^{16}$ It can be noted that the syntactical context is not exactly the same. In the first case, the Direct Object (DO) appears at the beginning, something that is not normally the case, whilst in the second question the Subject is not placed in the usual location, at the beginning, either.

${ }^{17}$ In locations 138, 144 and 146, the response of article + PN was collected only in one of the questions. In Maceda (144), the article appeared in the PN with the function of subject (o Felipe), whilst in Arbo (138) and O Bolo (146) it appeared in the PN wth the function of a DO (ao Miguel).
} 
There are three questions from the questionnaire which can be employed in order to know the geographical extension of the 'article $+\mathrm{PN}^{\prime}$ ' construction. In order to corroborate whether the syntactic context exercised an influence or not, the PN could be within the unit which functioned as a subject (8), as a Direct Object (DO) (9) or as a modifier of a noun phrase (10).

(8) O Xan é o noso veciño 'Xoán is our neighbour'.

(9) Ao Miguel collérono preso 'They took Miguel prisoner'.

(10) Os bens do Miguel 'Miguel's property'.

On many occasions, the questions had double responses, i.e. in one or all of the questions, the informant from a location employs the PN with and without the article. This is a factor which confers greater value upon the ALGa data; it also represents a challenge in terms of representing that data.

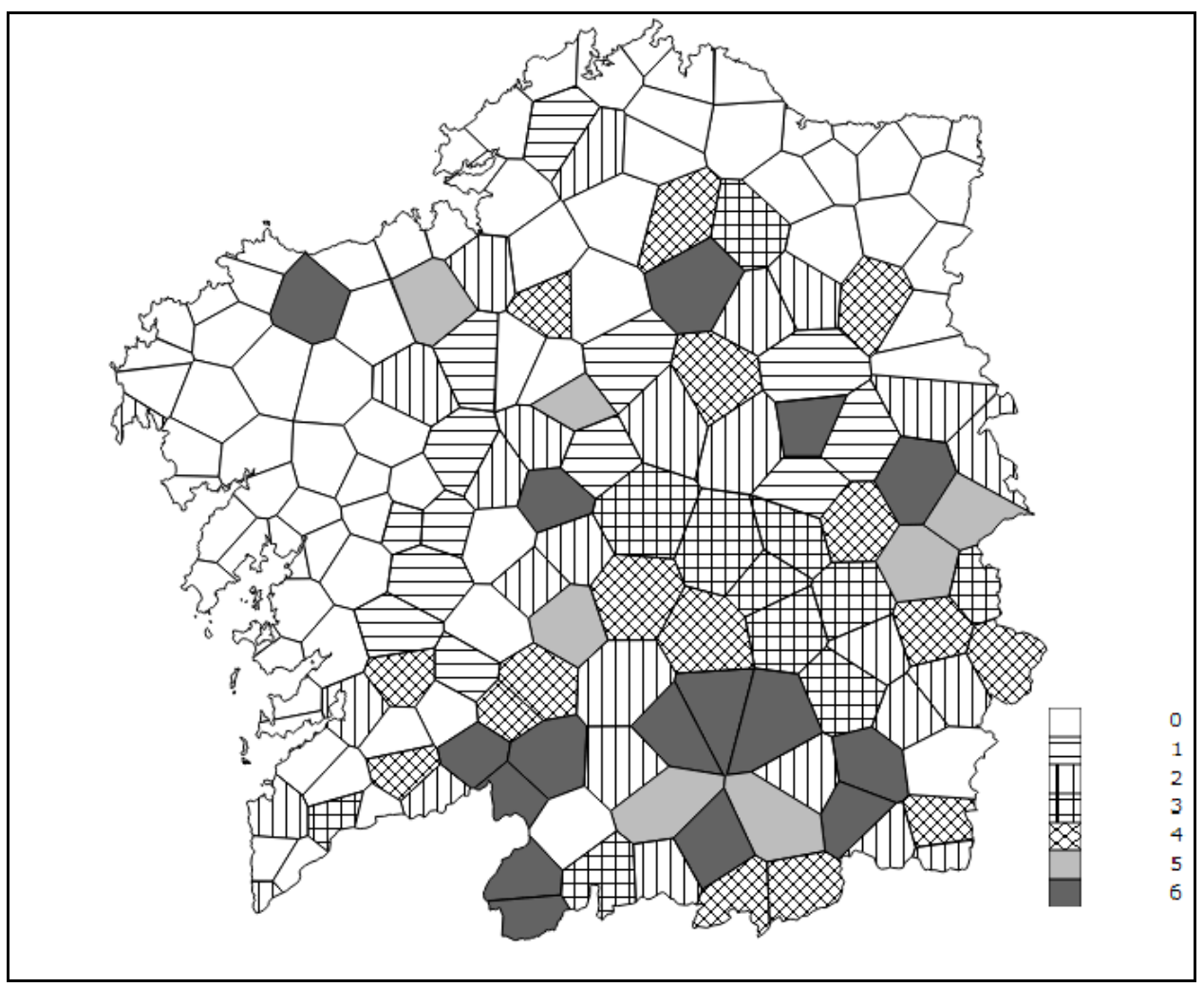

Map 2. Use of the article + PN according to the ALGa (Data from ALGa, questions 402, 477, 490) 
On Map 2 the data obtained from the ALGa's three questions listed above is displayed. In order to attempt to represent the variation in responses adequately, it was decided to assign a numeric value to each one of the possibilities. If the response to a question is only the variant with article, its value is 2 ; if the informant claims to be able to use or not use the article, the value assigned is 1 , whilst if the only option available is that without article then its value is 0 . This was the rule with the three question. Therefore, and for example, if the informant of a location claims to be able to use the article in each one of the syntactic contexts for which he or she is asked a question, the value assigned to this location is 6 , the sum of the maximum values for each question.

Map 2 includes the 'article $+\mathrm{PN}^{\prime}$ construction as a possible response in the majority of the territory, although with some differences. In Western Coruña, in the north of Lugo and in western Asturias, the phenomenon has little presence, whilst in the rest of the territory the occurrence of the structure is much greater, above all in Ourense province. I proposed before that by having three different syntactical contexts at our disposal, we can observe if this is a key determinant for the appearance of the article with the PN. Table 1 provides data regarding the number of locations surveyed

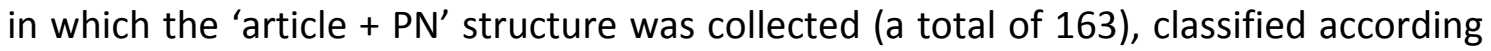
to the function of the PN in which they are included (Subject, Direct Object and PN modifier). If the structure was registered as a sole response or accompanying the variant PN without an article, then this is also taken into account.

\begin{tabular}{|c|c|c|c|}
\hline & Subject & Direct Object & PN Modifier \\
\hline Single Response & 70 & 24 & 29 \\
\hline Double Response & 13 & 31 & 9 \\
\hline Total & $\mathbf{8 3}$ & $\mathbf{5 5}$ & $\mathbf{3 8}$ \\
\hline
\end{tabular}

Table 1. Article + PN and syntactical function

We can see that the syntactical function which most favours the appearance of the article with the PN is that of Subject (83 locations), followed at quite a distance by the OD (55) and even more by the PN Modifier (38). An interesting fact is that the 
Dialectologia. Special issue, $\boldsymbol{V}$ (2015), 167-190.

ISSN: 2013-2247

'article $+\mathrm{N}$ ' structure functioning as a DO was recorded in more locations as one of the possible variants than as a single response.

\subsubsection{Study and comparison}

To have linguistic data collected in two temporal moments allows for an analysis from the perspective of change in real time. However, for a correct comparison of the two data sources some considerations must be taken into account. On the one hand, the locations surveyed by the two atlases coincide only partially since the ALGa also has a wider locations network than that of the ALPI (163 locations vs. 53). Moreover, the ALGa network includes 15 Galician-speaking locations from the provinces of Asturias, León and Zamora. On the other hand, several locations from the ALP were not chosen by ALGa researchers for the completion of the fieldwork (cf. Rodríguez 2008: 61).

Considering this, if we compare the two maps shows, we can reach a clear conclusion: the extension area of the 'article $+\mathrm{PN}^{\prime}$ phenomenon is much greater in Map 2 ( $A L G a)$ than in 1 (ALPI). Given that the ALGa is more recent, a plausible explanation would be to consider that, regarding absolute data, the phenomenon widened its extension between the 1930s and the 1970s.

Although it may be the most logical explanation, it does not mean that it is the correct one. Studies carried out on other linguistic phenomena by comparing data offered by ALPI and the ALGa (cf. Rodríguez Lorenzo 2008, 2012) show that the "differential" phenomena of Galicia, i.e. those that do not coincide with Castilian or with the majority variant in other Galician dialects, lose ground during the forty-year period which separates the two atlases. Given that the 'article $+\mathrm{PN}^{\prime}$ ' construction is one of these differential variants, it would be somewhat strange if it experienced a process of expansion and, furthermore, if this occurred so swiftly.

The causes of this apparent contradiction may lie, in our opinion, in the two atlases' enquiry methodology. As has been seen, the ALGa offers more than a response for a single question on many occasions. This feature is not frequent in the ALPI; it is 
actually very rare, above all in questions relating to morphosyntax. This variation is due to, in my opinion, an inclination towards accommodating within the ALGa phenomena of intralectal variation, i.e. within a single geographical location. Furthermore, the manner of formulating the questions by each team of researchers could have influenced the responses obtained. That is, the way of posing questions can cause distortions to occur. In theory, both atlases employ indirect enquiry methods, i.e., those which avoid mentioning the word or structure which is sought after. That is, the informant is not asked how a certain linguistic form is said, but is encouraged to use it more or less spontaneously.

My experience in the project of transcribing the materials of the ALPI caused me to be reasonably familiar with the responses to the syntactical questionnaire. The frequency of replies with structures traced from Castilian, which at that time must have been scarce, causes me to suspect that, at least regarding questions relating to syntax, the method of offering an utterance in Castilian to the informant in order that he or she used its equivalent in the local variety was employed. ${ }^{18}$ This way of proceeding is problematic in situations of linguistic contact as it can cause the informant to offer, within two possibilities, what most resembles that proposed by the interviewer, i.e. what most resembles Spanish (cf. De Benito 2010: 4). For 'article + $\mathrm{PN}^{\prime}$, this method of questioning may have caused the speakers to provide a literal translation as a response, word for word, from Castilian, which did not correspond with real usage. In the case of ALGa, however, the syntactical data is much more coherent than that obtained through other methods, such as the recording of spontaneous speech. The team of interviewers of this atlas affirmed shortly after completing the interviews (García et alii 1977) that indirect enquiry methods were employed and that Castilian was never used for the formulation of questions.

Finally, another factor should be added. It is possible that the intention of the ALPI and ALGa teams was not the same at the time of collecting and representing the linguistic phenomena that were the focus of the study. In the syntax questions, it can

\footnotetext{
${ }^{18}$ This would contradict what is stated in the introduction to the sole volume of the ALPI (1962): "All questions were asked indirectly, even those consisting of phrases for the study of morphology and syntax" ("Todas las preguntas fueron hechas indirectamente, incluso las de las frases para el estudio de la morfología y la sintaxis").
} 
be observed that one of the objectives of the ALGa researchers is to register all the possible variants within a single location. Whilst in the ALPI the number of multiple responses is much scarcer.

In summary, the apparent greater extension of the 'article $+\mathrm{PN}^{\prime}$ ' construction in the ALGa must be interpreted in the light of these criteria. Such a rapid expansion of the phenomenon is unlikely. Therefore, the methodological differences appear to be crucial when working with syntatical data from both atlases.

\subsection{Theories concerning the origin and diffusion of the phenomenon in Galician}

Amongst the scarce works which have dealt with this question, those by Xulio Sousa (1994) and Carme Hermida (1986) can be highlighted. These authors offer two explanations, which can be seen as complementary, in order to justify the use of the article with the PN. That of Sousa (1994) is based on the set of oppositions of the language system, whilst that of Hermida (1986) is of a diachronic character. Sousa (1994) underlines that in the area where it is obligatory for the PN to appear with the article, the latter has a functional value, given that it permits the differentiation of the cases in which the noun has a referential value (cf. supra), as in (11), from those in which it has a denominative value (the name Antonio is referred to), as in (12).

O Antonio é feo 'Antonio [the person] is ugly'

Antonio é feo 'Antonio [the name] is ugly'

Meanwhile, in her study on the article in Galician, Hermida (1986) asserts that the use of the article with the PN in Galicia is due to a process of analogical extension. Given that the common nouns in Galician are accompanied in the majority of cases by the article (o can 'the dog', a casa 'the house', o home 'the man', etc.), this would imply that its use is extended to the PNs through a matter of linguistic symmetry. Unlike that of Sousa (1994), the proposal by Hermida (1986) would be acceptable for the entire territory, independently of whether it is obligatory to use the article with the PN or not. Nonetheless, it concerns two proposals with different objectives, whilst 
that of Sousa (1994) focuses on the web of structures within the group of oppositions in the system, and that of Hermida (1986) seeks to provide an account of the structure's origin. On the basis of these authors' contributions, I am now going to present two ideas which can help to explain the appearance and extension of the phenomenon. For this purpose, I refer to the monographs consulted regarding the PN and, above all, to the excellent study by C. Lyons (1999).

\subsection{A new research route}

The proposal made by Hermida (1986) seems essentially correct. The analogy is a habitual phenomenon in languages and a frequent cause of linguistic change. However, I believe that it is necessary to root this idea by taking advantage of the advances in linguistics in recent years. The analogy is a very common explanation in linguistic studies, but its explicative value is very low.

The article is a class of words existent in the majority of European languages. However, it does not have the same frequency in all of them. In his study, Lyons (1999) states that an implicative scale in languages seems to exist, in such a way that some languages use the article in few contexts, others in more, and others in practically allpossible contexts. According to this author, English is a language which employs the article in restricted contexts. Generic nouns, which denominate a class, appear without the article (Books are my better friends). In French, however generic nouns tend to be accompanied by the article (Les livres sont mes mellieur amis). In this language, however, the article is not used if the subjunctive is already determined through the possessive (Ma maison est tres confortable), something which does occur in languages such as Italian (La mia casa è confortevole). Finally, whilst in Italian the use of the article with the PN (Giussepe è il mio amico) is not obligatory, as we have seen, in Catalan and in other languages the use of the article is mandatory (El Jusep él meu amic). ${ }^{19}$

\footnotetext{
${ }^{19}$ For reasons of space, this matter cannot be developed further here. For this reason, the study by Lyons (1999) and the bibliography cited by him is referred to. It should be taken into account, however, that within each group of nouns, some exceptions exist. Therefore, the progression is not perfect, i.e. the article can appear with the PN without always appearing before the possessives. Furthermore,
} 
Christopher Lyons (1999), regarding the combination between article and possessive within the same linguistic unit, distinguishes between GD (Genitive Determiner) languages and GA (Genitive Adjectival). In the first, such as English, French or German, the article does not appear with the possessive (my book), whilst in GA languages, such as Galician, Italian or Catalan, Portuguese or Greek, the possessive is used normally with the article (o meu libro).

However, even in GA languages there are determined nouns which reject the combined use of article and possessive. This is the case of kinship nouns. This class of nouns can appear in Galician and other Romance languages with an article and possessive (o meu irmán 'my brother') or just with the possessive (meu irmán) as in GD languages. Therefore, kinship nouns (with the possessive) and the PN are those which least appear with the article.

As has been seen in the analysis of ALPI and ALGa data, in Galicia two linguistic areas exist according to the appearance or not of the 'article $+\mathrm{PN}^{\prime}$ structure. In one of these (Area A), this construction appears with greater or lesser frequency, and in another (Area B), it does not appear. My hypothesis for Galician is that kinship nouns should display a similar behaviour to that of PNs in terms of the use of the article. That is, the use of the article with the PN will be more habitual where the article with a kinship noun is also used. And vice versa, in the area where the kinship noun is used without the article, the PN will tend to appear also without the article. In order to see what are the territory's locations where the article appears with kinship nouns, I return once again to the ALGa data. This provides information regarding the use or not of the article with the kinship names tío 'uncle' and irmán 'brother' (questions 257 and 489).

Above all, it should be taken into account that previous studies show that the article appears more with some kinship nouns than with others. The nouns which designate descendency kinship, such as fillo-a ('son/daughter'), tend to appear more with the article whilst in those which refer to ascendency kinship, pai ('father') or avó

although the process has begun, it can be reversible. Thus, for example in medieval French and Castilian, the'article + possessive + name' sequence was possible and today is not (cf. Fernández-Ordóñez 2011; Company 2009; Pino 1996), whilst in other languages, such as Galician or Catalan, this structure broadened the uses which they had in the Middle Ages (Company 2009: 784). 
('grand father') it is more frequent for them to occur without the article (Varela, 1997; Silva Domínguez 2002: 69).

The data obtained from the ALGa demonstrates that in the sum of Galician varieties four possibilities exist with the use of the 'article $+\mathrm{PN}^{\prime}$ and 'article + pos. + kinship noun' constructions:

a) The article appears with the PN and the kinship noun.

b) The article is used with the PN more than with the kinship noun.

c) The article is not used with the PN or with the kinship noun.

d) The article does not accompany the PN but the kinship noun.

In accordance with the hypothesis proposed above, the locations where option a) and c) obtain should be more frequent than those in which option b) and d) obtain respectively. In table 2 , we see that in the locations where the article accompanies the $\mathrm{PN}$, the majority use of the article with kinship noun is also collected $(75 \%$ and $91 \%$ of the locations depending on the kinship noun, irmán or tío), whilst in the area where the article is used with the PN, area B, in the majority of the cases the article does not appear with the kinship noun (69\% e $71 \%$ ) either.

\begin{tabular}{|l|l|l|}
\hline & Area A (article + PN) & Area B (PN without article) \\
\hline Article + meu tío 'my uncle' & $75 \%$ & $31 \%$ \\
\hline Meu tío (without article) & $25 \%$ & $69 \%$ \\
\hline Article + meu irmán 'my brother' & $91 \%$ & $29 \%$ \\
\hline meu irmán (without article) & $9 \%$ & $71 \%$ \\
\hline
\end{tabular}

Table 2. Use of article with PN and kinship nouns

Some indications exist which support the hypothesis that the use of the article with the PN is due to a process of expansion of the use of the article. Firstly, in other languages in which the use of the article with the PN is obligatory or optional, the article is also very frequent, or obligatory, before possessives. Secondly, the knowledge of the internal history of Galician shows that the article becomes more frequent before possessives the closer we get to the Modern Age (Ferreiro $\left.1999^{4}: 257-258\right)$. In the Middle Ages it is more common that the 'possessive + name' constructions appear 
without the article. However, the 'article + possessive + noun' sequence is registered frequently, above all in non-literary texts.

Therefore, reasonable indications exist to suggest that the use of the article with the PN in Galicia must be framed within a process of the article's functional expansion, from the Middle Ages to the present (Silva 2002). However, against this expansion of the article, which implies using it in the PN, the language model regarded as being more learned and the model of Galician diffused through channels of communication and school is at play, and does not use the article with PNs.

\section{Conclusion}

In this study, the 'article $+\mathrm{PN}^{\prime}$ structure in Galician has been examined. This analysis consisted above all of the description and comparison of the linguistic atlas materials. The hypotheses which are sketched out regarding the phenomenon's origin are provisional and complement others which have been provided and should be treated with caution. For this reason, they should be interpreted as open study routes to other researchers. Moreover, the focus of this study is the Galician language. Therefore, what is discussed here cannot be applicable to other languages. It is necessary to have more data at our disposal, which must proceed from oral corpora.

After reflecting upon the linguistic characteristics of the article and of the PN, I have tried to show how this structure is common amongst many languages, with different levels of incidence. Likewise, through the examination of the linguistic geography data, I have sought to contribute to a better understanding of the dialectal reality of Galician and of its history. Through the comparison of two data sources, ALPI and ALGa, it has been shown how the syntactical data of the former must be interpreted with caution. The ignorance of the methodology employed and of the objectives can lead to erroneous conclusions.

Finally, based on previous studies regarding this matter, I have sought to relate the use of the article with the PN with the use of the article in noun phrases with a possessive. The data provided by linguistic atlases demonstrates that this hypothesis 
has foundation. Nevertheless, this explanation must be understood within the contribution of Lyons (1999) regarding the functional expansion of the article in typologically different languages.

This article represents just one more contribution to the analysis of a littlestudied construction until now. The study of the phenomenon requires a broad perspective which contemplates different data sources and which takes into account what occurs in similar languages. In regard to Galician, it is necessary, in my opinion, to widen the study by examining different texts, above all oral sources, which pertain to different registers (formal, colloquial, etc.) and, of course, which originate in different places. It would also be convenient to see not just if the article appears with a PN but also with other nouns of similar characteristics (kinship nouns, day names, etc.).

\section{References}

ALGa = GARCíA, C. \& A. SANTAMARINA (dirs.) (1994) Atlas Lingüístico Galego, vol. II: Morfoloxía Verbal, coord. by Rosario Álvarez Blanco, A Coruña: Fundación Pedro Barrié de la Maza/Instituto da Lingua Galega.

ALPI = Navarro Tomás (1962) Atlas Lingüístico de la Península Ibérica. Fonética, vol. I, Madrid: CSIC (various upublished material was also consulted).

ÁlvareZ, Rosario \& Xosé Xove (2002) Gramática da lingua galega, Vigo: Galaxia.

AMARAL, Eduardo Tadeu Roque (2003) A ausência/presença de artigo definido diante de antropônimos em três localidades de Minas Gerais: Campanha, Minas Novas e Paracatu, Unpublished Masters thesis, Belo Horizonte: Universidade Federal de Minas Gerais.

AmARAL, Eduardo Tadeu Roque (2008) Nomes próprios: análise de antropônimos no espanhol escrito, Doctoral thesis, São Paulo: Universidade de São Paulo.

ANDRÉs DíAZ, Ramón de (2013) Gramática comparada de las lenguas ibéricas, Gijón: Ed. Trea.

BRAGA, Luciene Maria (2012) Ausência/presença do artigo definido diante de antropônimos na fala dos moradores de Mariana e Uberaba-MG, Unpublished Masters thesis, Uberlândia: Universidade Federal de Uberlândia.

BRUCART, Josep M. (2008) “7. Els determinats”, in Joan Solá (dir.), Gramática del català contemporani, vol II. Sintaxi, Barcelona: Empúries, 1435-1516.

CARRILHO, Ernestina \& Xulio SOUSA (2012) "The geolinguistic background of Iberian Romance dialect syntax: Insights from the ALPI's materials", 7th Congress of the International Society for Dialectology and Geolinguistics (SIDG), Viena, 23-28 July 2012. 
Dialectologia. Special issue, $\boldsymbol{V}$ (2015), 167-190.

ISSN: 2013-2247

[http://webspersoais.usc.es/export/sites/default/persoais/xulio.sousa/pdfs/SIDG2012_Carrilho_ Sousa_24_7_12.pdf].

ChAmbers, J. K. \& Peter TRUdgill (1994) La Dialectología [translated by Carmen Morán González], Madrid: Visor.

CINTRA, Luís Filipe Lindley \& Celso CUNHA $\left(2000^{19}\right)$ Nova gramática do português contemporâneo, Lisboa: Sá da Costa.

COMPANy COMPany, Concepción (2009) "Artículo + posesivo + sustativo y estructuras afines", in C. Company Company, Sintaxis histórica de la lengua española. Segunda parte: la frase nominal, vol. 1, México: FCE/UNAM, 759-880.

COROMINA I POU, Eusebi (2001) L'article personal en català. Marca d'oralitat en l'escriptura, Unpublished doctoral thesis, Barcelona: Universitat Autònoma de Barcelona.

DARDANO, Maurizio \& Pietro TRIFONE (1995) La nuova grammatica della lingua italiana, Roma: Zanichelli.

De Benito Moreno, Carlota (2010) "Las oraciones pasivas e impersonales con se: estudio sobre el ALPI", Dialectologia, 5, 1-25. http://www.publicacions.ub.edu/revistes/dialectologia5/

ESCANDELL VIDAL, Ma Victoria (1997² [1995]) Los complementos del nombre, Madrid: Arco Libros.

FERnÁNDEZ LeBorÁNS, María Jesús (1999) “El nombre propio”, in Ignacio Bosque \& Violeta Demonte (dirs.), Gramática descriptiva de la lengua española, Madrid: Espasa, vol. I, 77-128.

Fernández-Ordóñez, Inés (2011) La lengua de Castilla y la formación del español, Madrid: Real Academia Española.

Ferreiro, Manuel (19994 [1996]) Gramática histórica galega. I Fonética e morfosintaxe, Santiago de Compostela: Laiovento.

GarcíA, Constantino et alii (1977) “O atlas lingüístico galego”, Verba, 4, 5-17.

García Moutón, Pilar (2010) "El procesamiento informático de los materiales del Atlas lingüístico de la Península Ibérica de Tomás Navarro Tomás", in Gotzon Aurrekoetxea \& José Luis Ormaetxea (eds.), Tools for Linguistic Variation, Bilbao: Euskal Herriko Unibersitatea, 167-174.

GARY-PRIEUR, Marie-Noëlle (1994) Grammaire du nom propre, Paris: Presses Universitaires de France.

Goosse, André (1993) Le bon usage. Grammaire française, Paris: Duculot.

HERMIDA GULíAS, Carme (1986) O artigo en galego. Undergraduate dissertation (unpublished), Santiago de Compostela: Universidade de Santiago de Compostela.

LYONS, Christopher (1999) Definiteness, Cambridge: Cambridge University Press.

Miguel, Matilde \& Eduardo Buzaglo Paiva Raposo (2013) “Determinantes", in E. B. P. Raposo et alii (2013a), Gramática do Português, vol. I, Lisboa: Fundação Calouste Gulbenkian, 819-882.

Ortiz CiscomanI, Rosa María (2009) “Capítulo 3. La creación y generalización del artículo”, in C. Company Company (2009a), Sintaxis histórica de la lengua española. Segunda parte: la frase nominal, vol. 1, México: FCE/UNAM, 271-386.

Pino SerRANO, Laura (1996) "Sobre a construcción Artigo + Posesivo + Nome nas linguas Románicas. Achega para un estudio comparativo", in Ramón Lorenzo \& Rosario Álvarez: Homenaxe á 
profesora Pilar Vázquez Cuesta, Santiago de Compostela: Universidade de Santiago de Compostela, 213-226.

RAPoso, Eduardo Buzaglo Paiva (2013) “Nomes próprios", in E. B. P. Raposo et alii, Gramática do Português, vol. I, Lisboa: Fundação Calouste Gulbenkian, 993-1044.

REYNOSO NOVERón, Jeanett (2006) "La determinación de la frase nominal con núcleo nombre propio. Un acercamiento histórico", in José Jesús de Bustos Tovar \& José Luis Girón Alconchel (eds.), Actas del VI Congreso Internacional de Historia de la Lengua Española, vol. II, Madrid: Arco Libros, 1047-1058.

REYNOSO NOVERÓN, Jeanett (2008) “El género textual y la sintaxis del nombre propio. Estudio histórico", in Concepción Company Company \& José G. Moreno de Alba, Actas del VII Congreso Internacional de Historia de la Lengua Española, vol. II, Madrid: Arco Libros, 2119-2130.

RODRíGUEZ LORENZO, David (2008) Evolución diatópica da gheada no século XX: análise contrastiva dos materiais que ofrece a xeografía lingüística, Supervised Research Study (unpublished), Santiago de Compostela: Universidade de Santiago de Compostela.

RodríGUez LoRENZO, David (2012) "The diatopic development of aspects of twentiethcentury Galician. A contrastive analysis of geographic linguistic data", Dialectologia, special Issue III, 143-156. < http://www.publicacions.ub.edu/revistes/dialectologiaSP2012/>

SILVA DOMínGUEZ, Carme (2002) Frases nominais con posesivo en galego. Estructura e valores referenciais. Supplement 50 of Verba. Anuario Galego de Filoloxía, Santiago de Compostela: Universidade de Santiago de Compostela.

SOUSA FERNÁNDEZ, Xulio (1994) “O artigo cos nomes propios de persoa no galego moderno", in R. Lorenzo (coord.), Actas do XIX Congreso Internacional de Lingüística e Filoloxía Románicas. Universidade de Santiago de Compostela, 1989, vol. VI, A Coruña: Fundación Pedro Barrié de la Maza, 309-316.

SOUSA FernÁndeZ, Xulio (2008) “Notas sobre o Atlas Lingüístico de la Península Ibérica en Galicia”, in M. Brea, F. Fernández Rei \& X. L. Regueira: Cada palabra pesaba, cada palabra medía. Homenaxe a Antón Santamarina, Santiago de Compostela: Universidade de Santiago de Compostela, 299-306.

VAn LANGENDONCK, Willy (2007) Theory and Tipology of Proper Names, Berlin: Mouton de Gruyter.

VARela VÁzQuez, Begoña (1997) “Os posesivos con substantivos de parentesco", in Benigno Fernández Salgado (ed.), Proceedings of the 4th International Conference on Galician Studies: University of Oxford, Oxford: Oxford Centre for Galician Studies, 353-373.

VÁzquez CuestA, Pilar \& Maria Albertina Mendes dA Luz $\left(1971^{3}\right)$ Gramática portuguesa, vol, I, Madrid: Gredos. 